\title{
PSORIASIS PUSTULOSA GENERALISATA DAN PEMFIGUS FOLIASEUS PADA SEORANG PASIEN YANG DITERAPI DENGAN KOMBINASI METOTREKSAT DAN AZATIOPRIN
}

\author{
Yola Fadilla, Dia Febrina, Nia Srie Haryati, Oki Suwarsa, Hartati Purbo Darmadji \\ Departemen Ilmu Kesehatan Kulit dan Kelamin, \\ FK Universitas Padjajaran/RSUP dr. Hasan Sadikin Bandung
}

\begin{abstract}
ABSTRAK
Psoriasis disertai penyakit bulosa autoimun yang terjadi pada satu orang sangat jarang terjadi. Diduga terdapat peranan plasminogenactivator, predisposisi genetik, atau faktor pencetus infeksi dalam patogenesis psoriasis yang disertai pemfigus foliaseus. Metotreksat dilaporkan efektif sebagai terapi psoriasis pustulosa dan azatioprin sebagai terapi penyakit bulosa autoimun menimbulkan efek samping yang lebih dapat ditoleransi.

Dilaporkan seorang pasien laki-laki berusia 38 tahun dengan diagnosis psoriasis pustulosa generalisata disertai pemfigus foliaseus. Selain gambaran klinis, diagnosis psoriasis pustulosa ditegakkan dengan pemeriksaan histopatologis, sedangkan diagnosis pemfigus foliaseus ditegakkan melalui pemeriksaan histopatologis dan direct immunofluorescence (DIF). Pasien diterapi dengan kombinasi metotreksat $3 \times 5 \mathrm{mg} / \mathrm{minggu}$ dan azatioprin 2x100 mg/hari. Setelah dua minggu mendapat terapi kombinasi, terjadi perbaikan klinis dan tidak ditemukan lesi baru.

Psoriasis dan penyakit bulosa autoimun pada satu orang sulit terapinya karena penggunaan dan penghentian kortikosteroid sistemik dapat mencetuskan psoriasis pustulosa. Pada pasien ini, dipilih metotreksat sebagai terapi psoriasis pustulosa generalisata karena efektivitasnya baik dan tersedia di Indonesia. Azatioprin diberikan untuk terapi pemfigus foliaseus atas pertimbangan efek samping yang jarang terjadi dibandingkan obat imunosupresan lainnya.

Dilaporkan satu pasien usia 38 tahun dengan psoriasis pustulosa generalisata disertai pemfigus foliaseus yang mendapatkan terapi kombinasi metotreksat $3 \times 5 \mathrm{mg} /$ minggu dan azatioprin $2 \times 100 \mathrm{mg} / \mathrm{hari}$. Perbaikan klinis didapatkan setelah dua minggu pengobatan.
\end{abstract}

Kata kunci: azatioprin, metotreksat, pemfigus foliaseus, psoriasis pustulosa generalisata

\section{CONCOMITANT OF GENERALIZED PUSTULAR PSORIASIS AND PEMPHIGUS FOLIACEUS WHICH WAS TREATED WITH COMBINATION OF METHOTREXATE AND AZATHIOPRINE}

\begin{abstract}
Psoriasis concomitant with autoimmune bullous diseases in one person is very rare. It was thought that there was a role of plasminogen activator, genetic predisposition, or infection in the pathogenesis of psoriasis concomitant with pemphigus foliaceus.Methotrexate is effective as a therapy for pustular psoriasis. Azathioprine as a therapy for autoimmune bullous-disease has more tolerableside effects.

A case of generalized pustular psoriasis concomitant with pemphigus foliaceus in a 38 year old male was reported.Besides the clinical picture, the diagnosis of pustular psoriasis was made by histopathological examination and the diagnosis of pemphigus foliaceus was made by histopathological examination and direct immunofluorescence (DIF). The patient was treated with combination of methotrexate $3 \times 5 \mathrm{mg} /$ week and azathioprine $2 \times 100 \mathrm{mg} /$ day. After two weeks of therapy, there was clinical improvement and no new lesion appeared.

Therapy of pustular psoriasis concomitant with pemphigus foliaceus was difficult because the usage and withdrawal of systemic corticosteroid might induce pustular psoriasis. In this patient, the choice of methotrexate for treating generalized pustular psoriasis due to its efficacy and availability Indonesia. Azathioprine was used for pemphigus foliaceus therapy due to its less side effects compared to other immunosuppressant drugs. Clinical improvement was achieved after two weeks of methotrexate and azathioprine combination therapy.
\end{abstract}

Key words:azathioprine, generalized pustular psoriasis, methotrexate, pemphigus foliaceus

Korespondensi:

Jl. Pateur 38, Bandung 40161

Telp Kantor : 0222032426

Email: 


\section{PENDAHULUAN}

Beberapa penyakit autoimun dapat terjadi pada satu orang. ${ }^{1,2}$ Kasus psoriasis pernah dilaporkan terjadi bersama penyakit autoimun lain, misalnya miastenia gravis, penyakit Crohn, kolitis ulseratif, lupus eritematosus sistemik, dan penyakit bulosa autoimun., ${ }^{2,3}$ Komorbiditas penyakit psoriasis dengan penyakit bulosa autoimun pertama kali dilaporkan pada tahun 1929 oleh Bloom dkk. ${ }^{1,4}$ Sejak tahun 1929 sampai dengan tahun 2015, beberapa kasus psoriasis dan penyakit bulosa autoimun yang terjadi pada satu orang telah dilaporkan, tetapi hubungan antara kedua penyakit tersebut masih belum jelas. ${ }^{4}$ Pemfigus foliaseus yang bersamaan dengan psoriasis sangat jarang terjadi. ${ }^{5}$ Sampai tahun 2011, hanya terdapat tujuh kasus psoriasis vulgaris disertai pemfigus foliaseus yang pernah dilaporkan pada literatur Inggris. ${ }^{6}$ Sepengetahuan penulis sampai saat ini belum ada kasus psoriasis pustulosa disertai pemfigus foliaseus yang telah dilaporkan sebelumnya.

Penyakit bulosa autoimun dan psoriasis yang terjadi pada satu orang sulit diterapi karena penggunaan dan penghentian kortikosteroid sistemik dapat mencetuskan psoriasis pustulosa. ${ }^{7}$ Kombinasi asitretin dan azatioprin pada seorang pasien pemfigoid bulosa dan eritroderma karena psoriasis vulgaris dilaporkan efektif,, tetapi asitretin belum tersedia di Indonesia.

Berikut ini dilaporkan kasus psoriasis pustulosa disertai pemfigus foliaseus pada seorang laki-laki berusia 38 tahun yang diberikan terapi kombinasi metotreksat dan azatioprin. Kasus ini dilaporkan karena merupakan kasus yang sangat jarang terjadi, yaitu psoriasis pustulosa generalisata disertai pemfigus foliaseus pada seorang pasien. Pada pasien ini, pengobtan kombinasi metotreksat dan azatioprin efektif, sehingga terjadi perbaikan klinis.

\section{KASUS}

Seorang laki-laki, 38 tahun, pendidikan terakhir SMA, karyawan pabrik, dirawat di Rumah Sakit Hasan Sadikin (RSHS) dengan keluhan utama berupa luka lecet pada kedua tungkai atas dan bokong yang terasa perih. Dua bulan sebelumnya, pasien pernah dirawat di RSHS dengan keluhan timbul lepuh berisi cairan jernih yang terasa gatal pada hampir seluruh bagian tubuh. Awalnya berupa bentol yang menjadi lepuh pada lengan bawah kanan. Sebagian lepuh mudah pecah menjadi luka lecet dan keropeng. Sejak tujuh hari sebelum dirawat muncul bercak merah dan lepuh berdinding kendur yang mudah pecah meninggalkan luka lecet pada kedua tungkai atas. Keluhan disertai sisik dan keropeng pada kulit kepala berambut, wajah, badan, punggung, dan kedua lengan. Keluhan disertai dengan demam yang hilang timbul. Keluhan sariawan di rongga mulut disangkal. Riwayat penurunan berat badan diakui $3 \mathrm{~kg}$ selama 1 bulan terakhir. Tidak ada keluhan yang sama sebelumnya dan tidak dijumpai pada anggota keluarga lainnya.

Pasien pertama kali dirawat di RSHS 2 bulan sebelumnya, dengan diagnosis klinis pemfigoid bulosa, mendapat deksametason $15 \mathrm{mg} / \mathrm{hari}$ IV, tetapi kelainan kulit memburuk. Pemeriksaan histopatologis menunjukkan dermatosis subkorneal pustular, pengobatan ditukar dengan dapson 1x100 mg/hari hingga 2x100 mg/hari per oral, dan kelainan kulit membaik. Hasil pemeriksaan glucose-6-phosphate-dehydrogenase (G6PD) dalam batas normal. Namun terjadi anemia hemolitik sehingga dapson dihentikan. Walaupun demikian, karena lesi kulit membaik, maka pasien dipulangkan tanpa obat khusus. Satu minggu kemudian pasien dirawat kembali di RSHS dan dilanjutkan terapi dengan dapson 1x50 mg/hari per oral selama 5 hari, kemudian dihentikan karena terjadi anemia dengan $\mathrm{Hb}$ 8,3 g/dL. Pasien dibiopsi ulang untuk memastikan diagnosis. Hasil pemeriksaan histopatologis pada lengan atas kiri menunjukkan gambaran epidermis akantotik, rete ridges memanjang regular, pada satu bagian ditemukan infiltrat sel neutrofil subkorneal, tidak ditemukan bulla subkorneal, dan lapisan parakeratotik tidak teridentifikasi. Papilla dermis panjang dan clubshaped dengan pembuluh darah berdilatasi, diinfiltrasi sel limfosit, 'suprapapillary plate' tampak tipis. Hasil pemeriksaan histopatologis tersebut sesuai dengan early pustular psoriasis (Gambar 2).

Pada pengamatan hari ke-18, muncul beruntus berisi nanah di tengkuk, punggung, dan dada, yang terasa nyeri. Beruntus berisi nanah semakin bertambah banyak hampir di seluruh bagian tubuh disertai nyeri pada kedua lutut dan sendi siku kanan. Status dermatologikus didapatkan, pada hampir seluruh tubuh tampak lesi difus, tidak menimbul, kering, berupa makula eritema dan skuama. Pada hampir seluruh bagian tubuh kecuali wajah, kedua telapak tangan dan kedua telapak kaki tampak lesi multipel, sebagian konfluens, bentuk sebagian bulat, sebagian tidak teratur, berukuran $0,1 \times 0,1 \times 0,1 \mathrm{~cm}$ sampai $3 \times$ $2 \times 0,1 \mathrm{~cm}$, batas tegas, sebagian menimbul, sebagian kering, berupa pustula dan erosi.Terdapat lake of pus di punggung tangan kiri (Gambar 1). Hasil pemeriksaan Gram pada pustula di tengkuk dan dada tidak ditemukan bakteri Gram positif maupun Gram negatif. Hasil pemeriksaan Rheumatoid Factor (RF) negatif dan C-Reactive Protein (CRP) positif. Pasien didiagnosis dengan eritroderma karena psoriasis pustulosa generalisata dan psoriasis artritis di genu bilateral dan sendi siku dekstra. Pasien diberikan terapi metotreksat 3x5 mg/minggu.

Pada pengamatan hari ke-26, muncul lepuh berisi cairan jernih dan berdinding kendur di kedua paha, kedua lutut, dan kedua tungkai bawah yang terasa gatal. Lepuh berdinding kendur kemudian cepat pecah menjadi luka 
lecet yang terasa nyeri. Terdapat Nikolsky sign, Asboe Hansen sign, dan epidermolisis (Gambar 3). Lesi psoriasis pustulosa generalisata membaik, tidak terdapat pustula baru, dan nyeri sendi. Karena timbul lesi kulit baru dengan gambaran yang tidak sesuai dengan psoriasis pustulosa, maka dilakukan biopsi ulang pada lesi bula di tungkai bawah kanan. Hasil pemeriksaan histopatologis sesuai dengan pemfigus foliaseus dengan gambaran akantolisis lapisan granular epidermis, membentuk olah dengan atap lapisan korneum (Gambar 4). Hasil pemeriksaan direct immunofluorescence (DIF) terdapat endapan IgG kuat dan C3 sedang pada interselular epider- mis (Gambar 5). Pasien didiagnosis dengan eritroderma karena psoriasis pustulosa generalisata dan pemfigus foliaseus. Pasien diterapi dengan metotreksat 3x5 mg/minggu dan azatioprin 2x50 mg/hari. Pada pengamatan hari ke-40, muncul lesi baru berupa lepuh berdinding kendur di paha kanan belakang dan tungkai bawah kiri belakang. Dosis azatioprin dinaikkan menjadi 2x100 mg/hari. Pada evaluasi hari ke-14 pemberian kombinasi metotreksat 3x5 mg/minggu dan azatioprin 2x100 mg/hari, terjadi perbaikan klinis berupa makula eritema dan skuama yang berkurang. Lesi baru berupa pustul maupun bula tidak muncul kembali (Gambar 6).

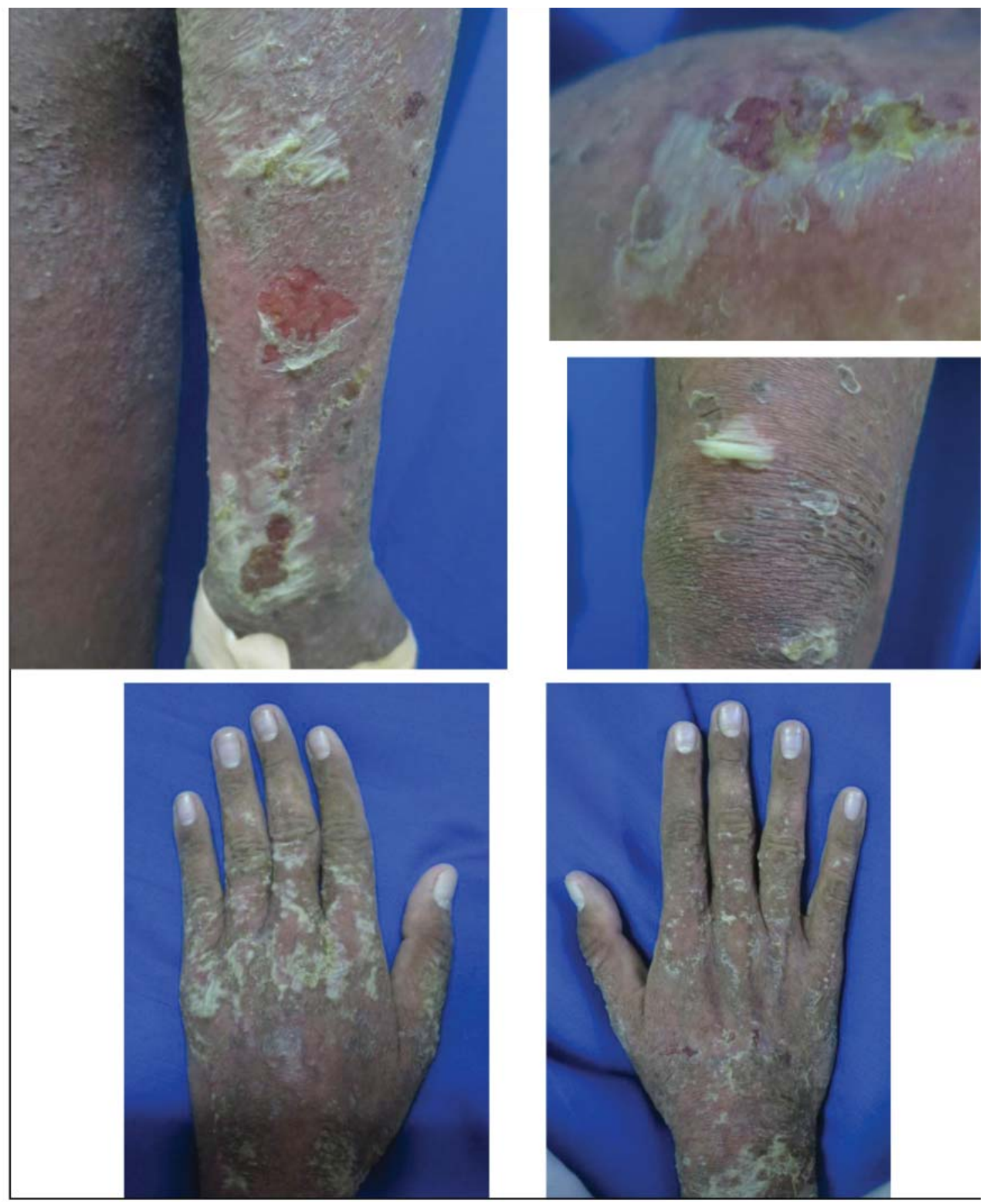

Gambar 1. Pengamatan hari ke-18: Tampak pustul dan lake of pus. 


\section{PEMBAHASAN}

Psoriasis bersama penyakit bulosa autoimun pada satu orang pertama kali dilaporkan pada tahun 1929 oleh Bloom dkk. ${ }^{1,4}$ Sejak tahun 1929 sampai dengan tahun 2015, telah dilaporkan beberapa kasus psoriasis dengan penyakit bulosa autoimun, tetapi hubungan antara kedua penyakit tersebut masih belum diketahui. ${ }^{4,8,9}$ Ohata dkk. ${ }^{4}$ melaporkan rasio lelaki dan perempuan yang terkena adalah 5,7:1.

Pada kasus ini, pasien merupakan seorang laki-laki berusia 38 tahun. Kelainan kulit berupa makula eritema dan bula kendur yang mudah pecah di kedua tungkai atas kemudian menjadi lecet yang terasa perih. Pasien pertama kali dirawat di RSHS dua bulan sebelumnya dan hasil pemeriksaan histopatologis berupa dermatosis pustular subkorneal. Pasien mendapat terapi dapson 1x100 mg/hari hingga 2x100 mg/hari per oral dan kelainan kulit membaik. Namun terjadi anemia hemolitik sehingga dapson dihentikan. Pasien pulang dengan perbaikan. Satu minggu kemudian pasien dirawat kembali di RSHS dan hasil pemeriksaan histopatologis ulang dengan kesimpulan psoriasis pustulosa awal. Pada pengamatan hari ke-18 timbul pustul pada hampir seluruh tubuh yang terasa nyeri dan terdapat lake of pus pada punggung tangan kiri. Keluhan juga disertai nyeri pada kedua sendi lutut dan sendi siku kanan. Hasil pemeriksaan RF negatif dengan CRP positif. Pasien didiagnosis kerja sebagai psoriasis pustulosa generalisata dan artritis psoriatik. Pada pengamatan hari ke-26, timbul vesikel dan bula berdinding kendur yang mudah pecah menjadi erosi di kedua paha, lutut, dan tungkai bawah. Nikolsky sign dan Asboe Hansen sign positif. Pemeriksaan histopatologis sesuai dengan pemfigus foliaseus dan hasil pemeriksaan DIF terdapat endapan IgG kuat dan C3 sedang pada interselular epidermis. Oleh karena itu, pasien didiagnosis dengan psoriasis pustulosa generalisata dan pemfigus foliaseus. Diagnosis tersebut didukung oleh hasil pemeriksaan histopatologis pada dua lesi yang berbeda. Hasil pemeriksaan histopatologis pada lesi makula eritema di lengan atas kiri memberikan gambaran psoriasis pustulosa awal, sedangkan hasil pemeriksaan histopatologis dan DIF pada lesi bula di tungkai bawah kanan menunjang diagnosis pemfigus foliaseus.

Penyakit bulosa autoimun tersering yang ditemukan bersama dengan psoriasis adalah pemfigoid bulosa., ${ }^{4,6}$ Pada kebanyakan kasus, psoriasis vulgaris mendahului awitan penyakit bulosa autoimun dengan rata-rata interval waktu 20 tahun. ${ }^{1,8}$ Ohata dkk. ${ }^{4}$ melaporkan lima kasus penyakit bulosa autoimun yang terjadi kurang dari lima bulan setelah awitan psoriasis pustulosa dan satu kasus yang terjadi bersamaan dari total 145 kasus psoriasis dan penyakit bulosa autoimun pada satu orang. Kasus psoriasis yang disertai pemfigus foliaseus sedikit sekali dilapor- kan, sehingga sulit untuk menyimpulkan apakah kejadian psoriasis bersama pemfigus foliaseus hanya merupakan kebetulan atau tidak.,5 Sampai tahun 2011 hanya terdapat tujuh kasus pemfigus foliaseus bersama psoriasis vulgaris yang pernah dilaporkan di Inggris. ${ }^{6}$ Sepengetahuan penulis sampai saat ini belum ada kasus psoriasis pustulosa dan pemfigus foliaseus yang dilaporkan sebelumnya. Pada pasien ini, psoriasis pustulosa mendahului awitan pemfigus foliaseus.

Patogenesis terjadinya penyakit bulosa autoimun dan psoriasis pada satu orang masih belum jelas. ${ }^{4,8}$ Salah satu hipotesis menyebutkan peran plasminogen activator (PA). ${ }^{2,10}$ Plasminogen activator adalah enzim proteinase serine yang berfungsi sebagai katalisator pada konversi plasminogen menjadi plasmin. Plasminogen activator dilaporkan meningkat pada lesi psoriasis. ${ }^{11}$ Sel makrofag, granulosit, sel granulosa ovarium, fibroblas, trofoblas, dan sel endotel menghasilkan PA. Ikatan imunoglobulin $\mathrm{G}$ pada antigen permukaan sel dapat meningkatkan produksi PA pada sel-sel tersebut. ${ }^{12} \mathrm{Hal}$ ini akan meningkatkan konversi plasminogen menjadi plasmin. Plasmin mendegradasi molekul-molekul di permukaan sel yang berperan pada adhesi antar sel epidermis sehingga menyebabkan akantolisis. ${ }^{11}$

Alel HLA-DRB1 juga dianggap berperan pada psoriasis vulgaris dan pemfigus foliaseus. ${ }^{5,6}$ Cardoso dkk. ${ }^{13}$ melaporkan alel HLA-DRB1*0102 ditemukan pada pasien psoriasis vulgaris sedangkan Pavoni dkk. ${ }^{14}$ melaporkan alel HLA-DRB1*0102 sebagai salah satu alel HLA yang sering ditemukan pada kasus endemik pemfigus foliaseus (fogo selvagem) di Brazil. Hipotesis lain menyebutkan peran infeksi bakteri streptokokus atau superantigen bakteri lainnya dalam patogenesis psoriasis dan penyakit bulosa autoimun. ${ }^{15}$ Organisme ini akan meningkatkan produksi imunoglobulin G (IgG) terhadap antigen keratinosit sehingga merangsang pembentukan bula. ${ }^{8,10}$

Terapi psoriasis dan penyakit bulosa autoimun pada satu orang sulit karena penggunaan dan penghentian kortikosteroid sistemik dapat mencetuskan psoriasis pustulosa. ${ }^{7}$ Kombinasi asitretin dan azatioprin pada pasien pemfigoid bulosa dan eritroderma karena psoriasis vulgaris dilaporkan efektif, ${ }^{8}$ tetapi asitretin belum tersedia di Indonesia. Pada pasien ini metotreksat dipilih untuk terapi psoriasis pustulosa generalisata karena efektivitasnya baik dan mudah didapat dibandingkan etretinat yang belum tersedia di Indonesia. Pada pasien ini azatioprin diberikan untuk terapi pemfigus foliaseus atas pertimbangan efek samping yang lebih sedikit dibandingkan obat imunosupresan lainnya.

Azatioprin adalah suatu analog purin sintetik yang dimetabolisme di tubuh menjadi 6-mercaptopurine (6$M P$ ), kemudian dianabolisis oleh enzim hypoxanthine- 
guanine phosphoribosyl transferase (HGPRT) menjadi 6-thioguanine (6-TG) yang menghambat sintesis DNA dan RNA sehingga menimbulkan efek imunosupresi. Azatioprin digunakan sebagai steroid-sparing agent dalam pengobatan penyakit bulosa autoimun, termasuk pemfigus vulgaris, pemfigoid sikatrisial, dan pemfigoid bulosa rekalsitran. ${ }^{16}$ Azatioprin merupakan obat imunosupresan yang paling sering digunakan karena efek samping yang lebih sedikit dibandingkan obat imunosupresan lainnya, misalnya siklofosfamid. ${ }^{17}$

Metotreksat adalah analog folat yang menghambat enzim dihidrofolat reduktase dan timidilat sintetase secara kompetitif dan irreversible sehingga mengurangi kadar folat dan timidilat yang dibutuhkan untuk sintesis DNA dan RNA. Metotreksat digunakan pada beberapa penyakit kulit, misalnya psoriasis, pemfigus vulgaris, pemfigoid bulosa dan lupus eritematosus sistemik. ${ }^{16,18}$ Pada psoriasis pustulosa, obat yang sering digunakan adalah etretinat, metotreksat, siklosporin, dan infliksimab. ${ }^{19}$ Etretinat merupakan terapi lini pertama pada psoriasis pustulosa. Efektivitas metotreksat sama dengan etretinat $^{20}$ dan tersedia di Indonesia.

Setelah didiagnosis psoriasis pustulosa generalisata disertai pemfigus foliaseus, pasien diterapi dengan kombinasi metotreksat 3x5 mg/minggu per oral selang 12 jam dan azatioprin 2x50 mg/hari per oral, kemudian dosis azatioprin dinaikkan menjadi 2x100 mg/hari karena masih timbul lesi baru pemfigus foliaseus. Pada evaluasi hari ke-14 pemberian kombinasi metotreksat dan azatioprin, terjadi perbaikan dengan berkurangnya makula eritematosa dan skuama serta tidak timbul lesi baru pemfigus foliaseus maupun psoriasis pustulosa.

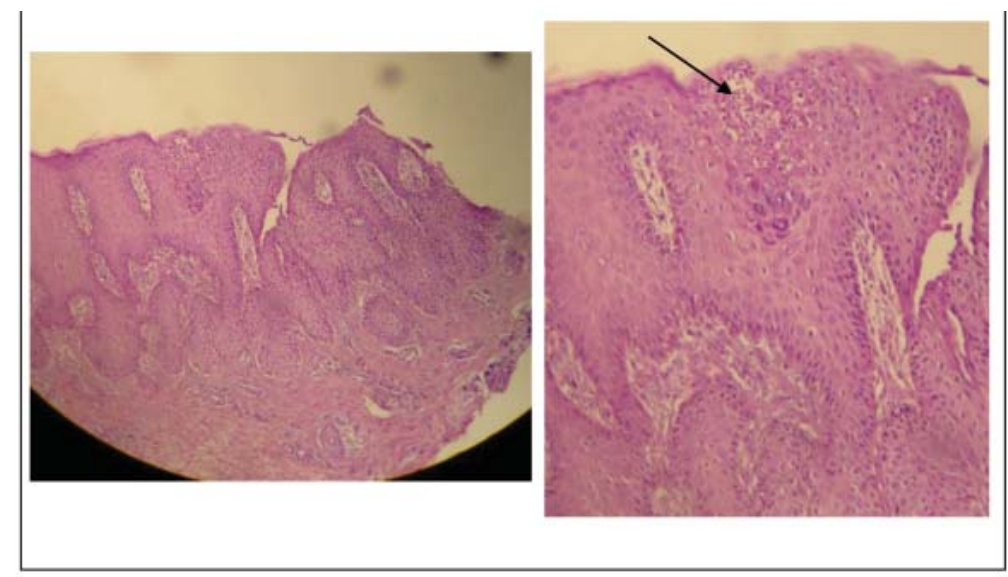

Gambar 2. Hasil pemeriksaan histopatologis: pada makula eritema di lengan atas kiri dengan gambaran Early pustular psoriasis.

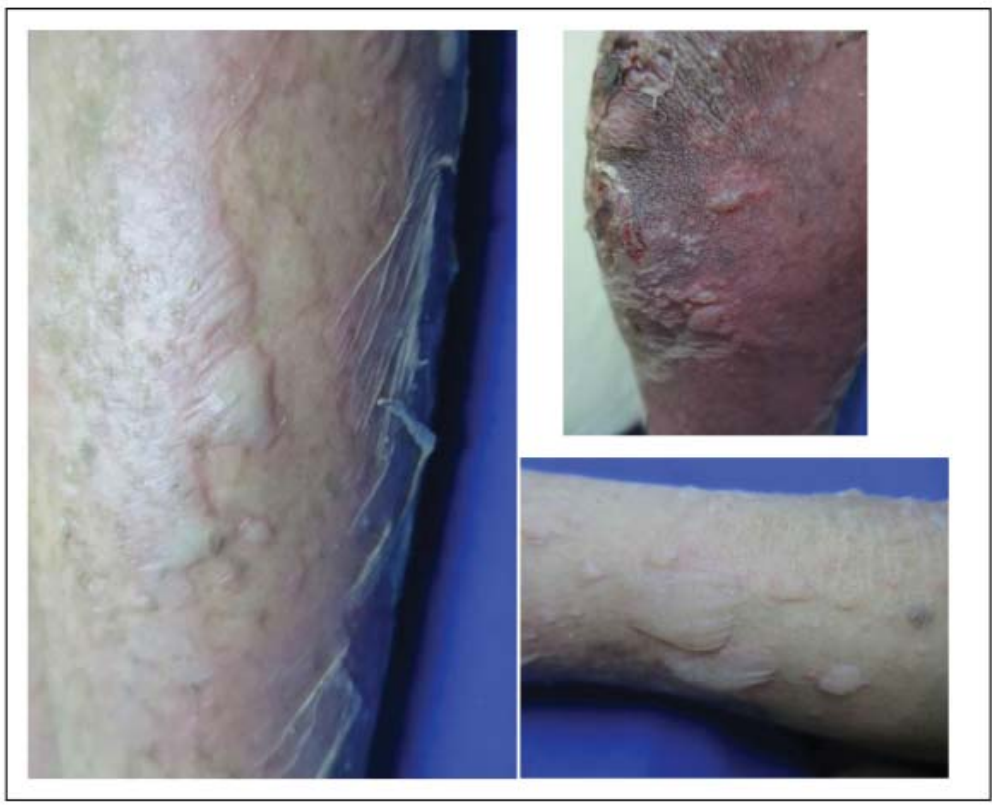

Gambar 3. Pengamatan pada hari ke-25: timbul bula berdinding kendur . 


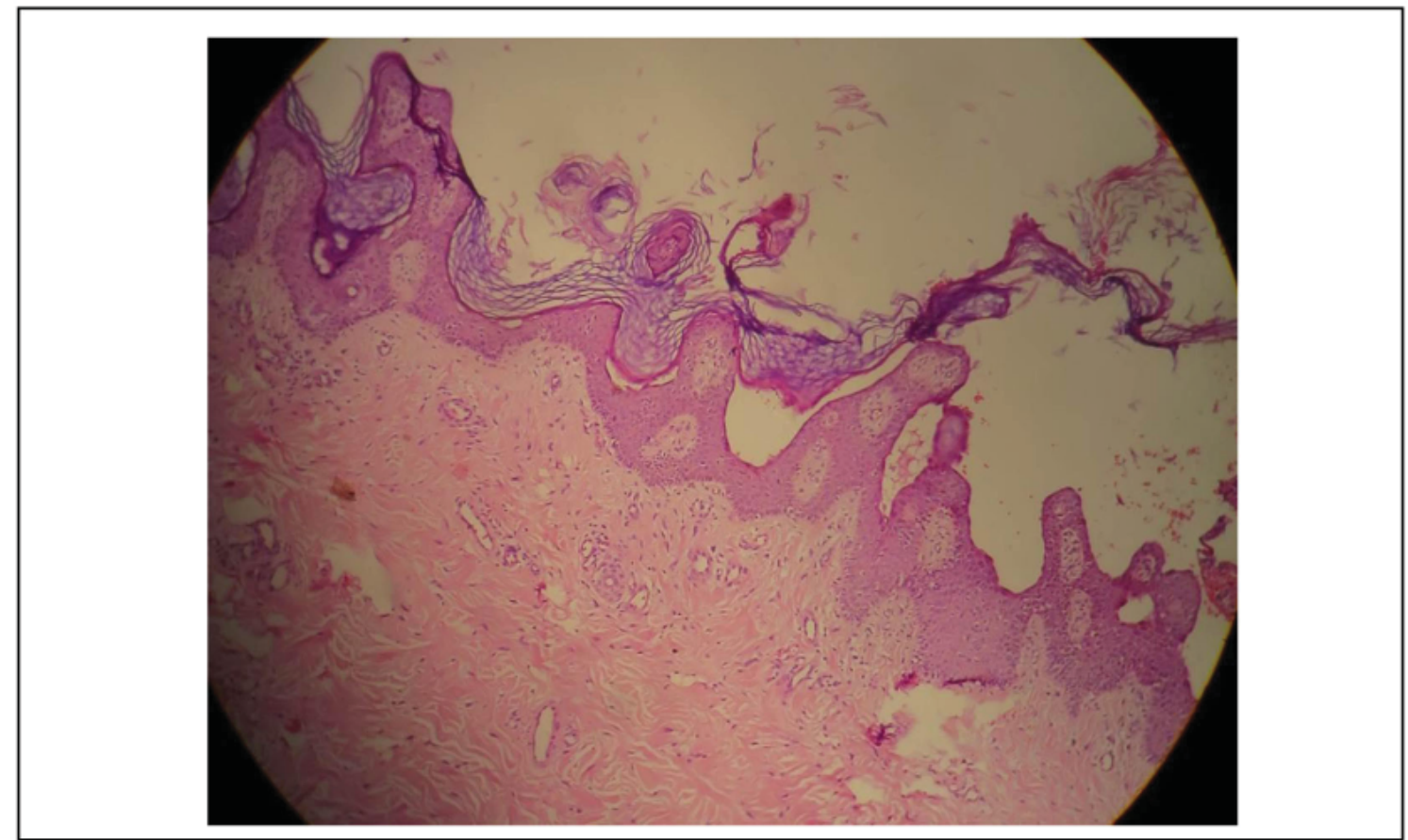

Gambar 4. Hasil pemeriksaan histopatologis: pada bula di tungkai bawah kanan memberikan gambaran pemfigus foliaseus

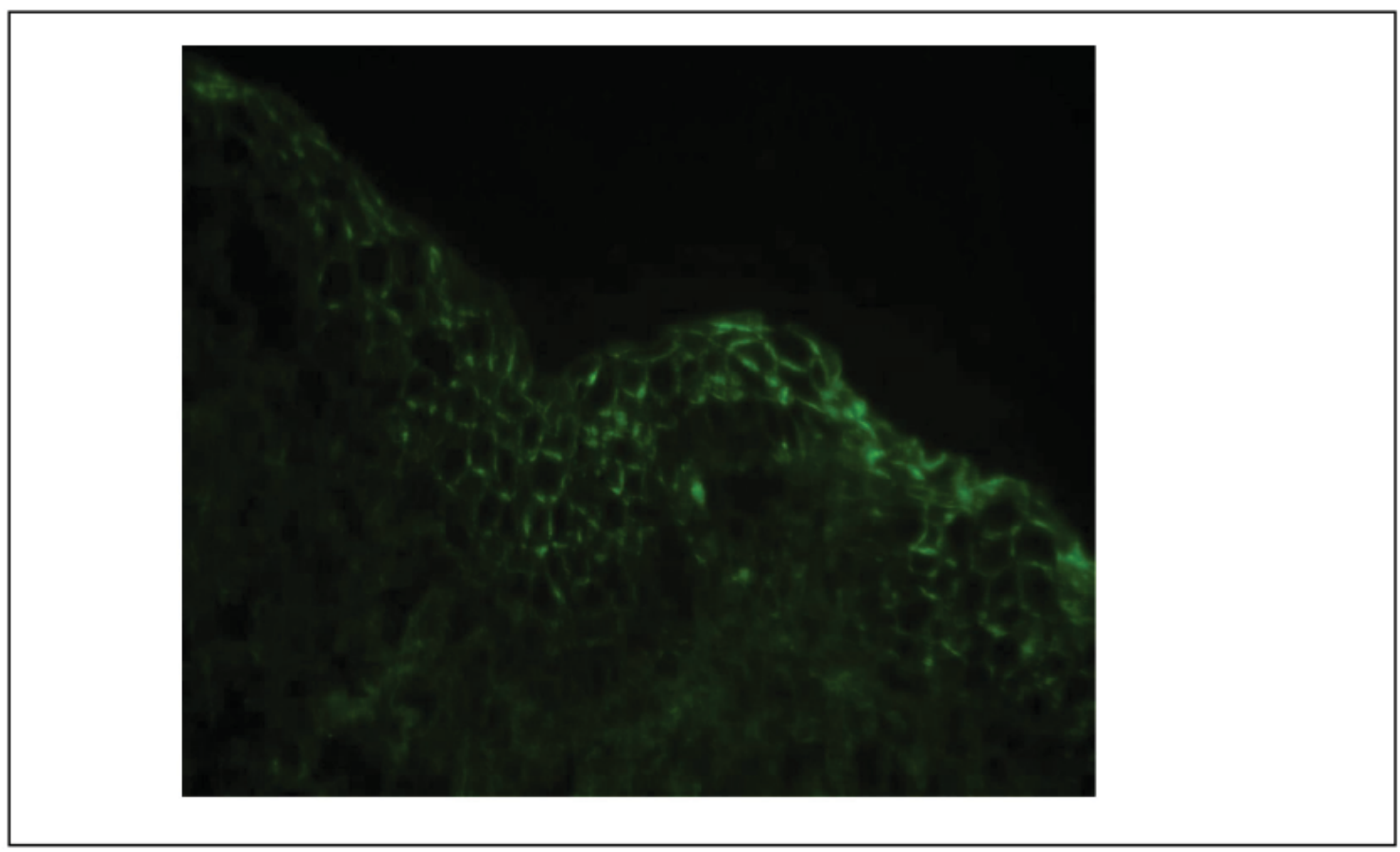

Gambar 5. Hasil pemeriksaan direct immunofluoresence: pada lesi bula di tungkai bawah kanan memberikan gambaran endapan IgG dan C3 pada epidermis interselular. 


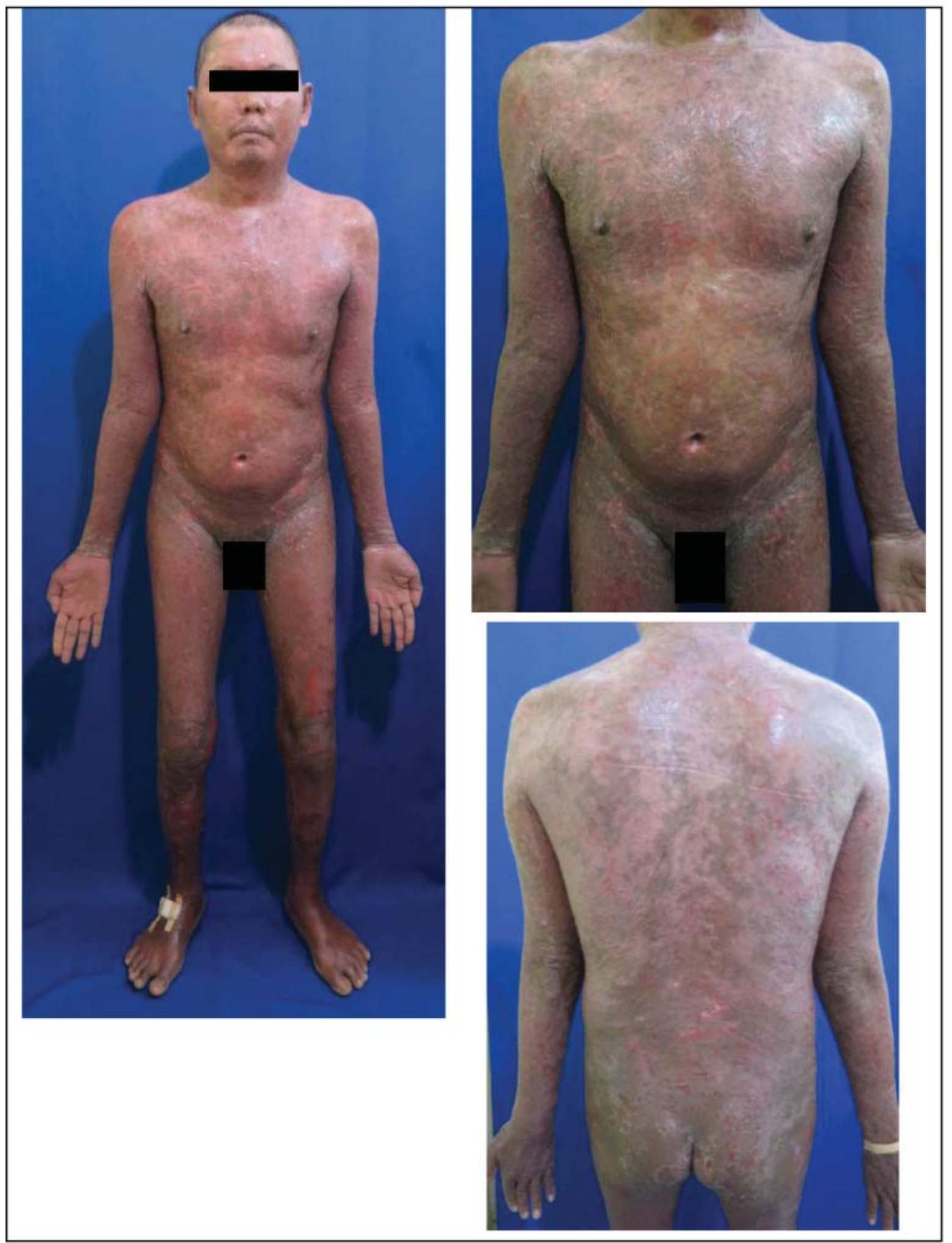

Gambar 6. Pengamatan pada hari ke-14 pemberian kombinasi metotreksat dan azatioprin. Makula eritema dan skuama berkurang. Tidak terdapat lesi baru psoriasis pustulosa dan pemfigus foliaseus 


\section{DAFTAR PUSTAKA}

1. Grunwald HG, David M, Feuerman EJ. Coexistence of psoriasis vulgaris and bullous diseases. J Am Acad Dermatol. 1985;13:224-8.

2. Yokoo M, Oka D, Ueki H. Coexistence of psoriasis vulgaris and pemphigus foliaceus. Dermatologica. 1989;179:222-3.

3. Rao R, Gupta A, Yunis F, Handettu S, Chandrashekar B. Coexistence of psoriasis with buloous pemphigoid. Indian Dermatol Online J. 2012;3(2):119-21.

4. Ohata C, Ishii N, Koga H, Fukuda S, Teteishi C, Tsuruta D, Furumura M, Hashimoto T. Coexistence of autoimmune bullous diseases (AIBDs) and psoriasis: a series of 145 cases. J Am Acad Dermatol. 2015;73:50-5.

5. Kurtzman DJB, Christopher M, Lian F, Sligh JE. A blistering response: concurrent psoriasis and pemphigus foliaceus. Am J Med. 2015;128:24-6.

6. Kwon HH, Kwon IH, Chung JH, Youn JI. Pemphigus foliaceus associated with psoriasis during the course of narrowband UVB therapy: a simple concidence? Ann Dermatol. 2011;23:281-4.

7. Yamauchi PS, Lowe NJ, Gindi V. Treatment of coexisting bullous pemphigoid and psoriasis with the tumor necrosis factor antagonist etanercept. J Am Acad Dermatol. 2006;54:121-2.

8. Wilczek A, Sticherling M. Concomitant psoriasis and bullous pemphigoid: coincidence or pathogenic relationship? Int J Dermatol. 2006;45:1353-7.

9. Saeki H, Hayashi N, Komine M, Soma Y, Shimida S, Watanabe $\mathrm{K}$, Hashimoto T. A case of generalized pustular psoriasis followed by bullous disease: an atypical case of bullous pemphigoid or a novel bullous disease. Br J Dermatol. 1996;134:152-5

10. Giomi B, Cardinali C, Pestelli E, Caproni M, Fabbri P. Pemphigus foliaceus developing on pre-existing psoriasis: a supposed pathogenetic linkage. Acta Derm Venereol. 2003;84:82-3.
11. Fraki JE, Lazarus GS, Gilgor RS, Marchase P, Singer KH. Correlation of epidermal plasminogen activator activity with disease activity in psoriasis. Br J Dermatol. 1983;108:3944.

12. Hashimoto K, Shafran KM, Webber PS, Lazarus GS, Singer $\mathrm{KH}$. Anti-cell surface pemphigus autoantibody stimulates plasminogen activator activity of human epidermal cells. J Exp Med. 1983;157:259-72.

13. Cardoso CB, Uthida-Tanaka AM, Magalhaes RF, Magna LA, Kraemer MHS. Association between psoriasis vulgaris and MHC-DRB, -DQB genes as a contribution to disease diagnosis. Eur J Dermatol. 2005;15:159-63

14. Pavoni DP, Roxo VMMS, Filho AM, Petzl-Erler ML. Dissecting the associations of endemic pemphigus foliaceus (fogo selvagem) with HLA-DRB1 alleles and genotypes. Genes Immun. 2003;4:110-6.

15. Ho CK. A case of pemphigus foliaceus co-existing with psoriasis. Hong Kong Dermatol Venereol Bull. 1999;7175-9.

16. High WA, Fitzpatrick JE. Cytotoxic and antimetabolic agents. Dalam: Wolff K, Goldsmith LA, Katz SI, Gilchrest BA, Paller AS, Leffel DA, penyunting. Fitzpatrick's dermatology in general medicine. Edisi ke-8 . New York: Mc Graw- Hill. 2012. hlm 2735-58.

17. Ioannides D, Lazaridou E, Rigopoulos D. Pemphigus. J Eur Acad Dermatol Venereol. 2008;22:1478-96.

18. Callen JP, Kulp-Shorten CL. Methotrexate. Dalam: Wolverton SE, penyunting. Comprehensive dermatologic drug therapy. Edisi ke-3. Indianapolis: Elsevier. 2013. hlm 182-9.

19. Gudjonsson JE, Elder JT. Psoriasis. Dalam: Wolff K, Goldsmith LA, Katz SI, Gilchrest BA, Paller AS, Leffel DA, penyunting. Fitzpatrick's dermatology in general medicine. Edisi ke-8. New York: Mc Graw- Hill. 2012. hlm 197-231.

20. Griffith CEM, Barker JNWN. Psoriasis. Dalam Burns T, Breathnach S, Cox N, Griffiths C, penyunting. Rook's textbook of dermatology. Edisi ke-8. West Sussex: Wiley-Blackwell. 2010. hlm 871-929. 
